\title{
Design of Foreign Language Evaluation System for Application-Oriented Colleges Based on MOOC
}

\author{
Wanwan Zhang, 2 * \\ ${ }^{1}$ School of Foreign Language \\ Pingxiang University \\ Pingxiang, China \\ ${ }^{2}$ Faculty of Asian Languages and Cultures \\ Guangdong University of Foreign Studies \\ Guangzhou, China \\ yang505412@163.com
}

\author{
Fang Liu \\ School of Foreign Language \\ Pingxiang University \\ Pingxiang, China \\ yang505412@163.com
}

\begin{abstract}
As an essential aspect of foreign language teaching, evaluation model plays an important role in the promotion of teaching quality and effect. The paper explores the evaluation model in the MOOC environment and its influence of foreign language teaching for application-oriented colleges, based on the “The Second Foreign Language” MOOC teaching. Furthermore, the feasibility of diversification evaluation model is studied in this paper on the bas is of combination of formative and terminative evaluation. The paper provides a new thinking for the evaluation of foreign language teaching for application-oriented colleges.
\end{abstract}

Keywords-MOOC; Teaching Evaluation; the Second Foreign Language; Application-Oriented Colleges

\section{INTRODUCTION}

The requirement that college English teaching should establish the diversified evaluation system based on the combination of formative assessment and summative assessment, is proposed by "Basic Requirements of College English Teaching (Trial)" from Ministry of Education. Accordingly, the regulations take the comprehensive application ability of students' language as a starting point, and point out the direction for reform of foreign language evaluation system in China. As an essential part of foreign language teaching, evaluation mode plays an important role in promotion of teaching quality and effect. With the development of information technology, MOOC has been widely applied in foreign language teaching in colleges and universities, resulting in profound changes in the concept and structure of foreign language teaching in China. Therefore, it is necessary to practice and study the evaluation mode of MOOC teaching in foreign language teaching.

The application-oriented colleges and universities are proposed to deepen the reform of higher education and actively promote the transformation and development of universities. They pay more attention to the training of students' application ability, and their teaching emphasis on "application", which are different from research universities. In addition, the course teaching based on MOOC is much better than the past video open class. It can simulate online teaching and offline teaching, and also have the characteristics

The paper is supported by "The Youth Project of Humanities and Social Sciences in Colleges and Universities of Jiangxi (YY17224)”. of the teaching in the overturned class. Accordingly, it is of theoretical and practical significance to design the evaluation system of foreign language teaching based on MOOC.

\section{COMPARISON OF FOREIGN LANGUAGE TEACHING EVALUATION}

According to the requirements of foreign language teaching from Ministry of Education, the colleges should adapt to the autonomous learning in foreign language teaching, by improving the exist evaluation method based on summative assessment and increasing the content of the formative evaluation. On the one hand, formative evaluation emphasizes the evaluation of students' learning process, provides feedback information, and evaluates the development of students' emotions, attitudes and learning strategies. On the other hand, summative assessment is the evaluation of the quality of teaching in a learning section or a subject, which aims at making a conclusive evaluation of the quality of students' phased learning.

The research and application of formative assessment started late in China, and lots of teachers have a deep-rooted understanding of the traditional evaluation mode. However, teachers and students have realized that the evaluation model combining formative and terminative evaluation can be better integrated with teaching, through the repeated demonstration of experts and scholars. It is beneficial to the perfection and development of teaching and learning process, to help students to form a personalized learning method, to give full play to the students' self-learning ability, and to play a positive backwash effect on teaching, which is a practical and feasible evaluation model. Actually, the previous research and application are based on the traditional teaching model, and the research on the evaluation model of a specific class in the MOOC teaching environment is rare. Whether the combination of formative evaluation and summative evaluation is suitable to the widely used MOOC teaching mechanism, and how the elements of the formative evaluation are embodied in the MOOC environment, makes the research in carrying out the evaluation of MOOC based foreign language teaching in applicationoriented colleges and universities very important. In a word, it shows in the following aspects. 
- As a pilot, the reform of teaching mode and evaluation mode in application-oriented colleges and universities can promote the transformation. Meanwhile, the quality of teaching reform can be revealed quickly, and the research results can be extended to other applicationoriented colleges and universities.

- Foreign language courses are general education courses, and the frequency in daily learning and life is much higher than other courses. Moreover, the cultivation of comprehensive foreign language proficiency is difficult to achieve through a single summative assessment, which makes it necessary to introduce formative assessment in foreign language teaching.

- The teaching environment based on MOOC has been relatively mature after years of practice teaching, and students can skillfully use various MOOC teaching environments. It is easier for teachers and students to accept from research on the evaluation mechanism of foreign language courses, and it has achieved excellent effect in research and practice.

The traditional evaluation of foreign language teaching is completed through summative assessment, it means that the examination is conducted at the end of the term or at the end of the semester, and the examination results are taken as the evaluation basis. The evaluation mode in MOOC teaching environment is essentially different from the traditional teaching evaluation mode. On the one hand, the evaluation of the traditional teaching emphasis on summative evaluation, and takes the final examination performance as the main evaluation criterion, while the MOOC teaching evaluation is based on the formative evaluation and the evaluation of the daily learning. On the other hand, the traditional teaching and evaluation are independent of each other, and the evaluation results affect the teaching process and the result of learning through the feedback mechanism. The evaluation of the MOOC teaching is embedded in the teaching process, which directly affects the teaching process and affects the learning results. The differences between traditional teaching and MOOC teaching are shown in Fig. 1.

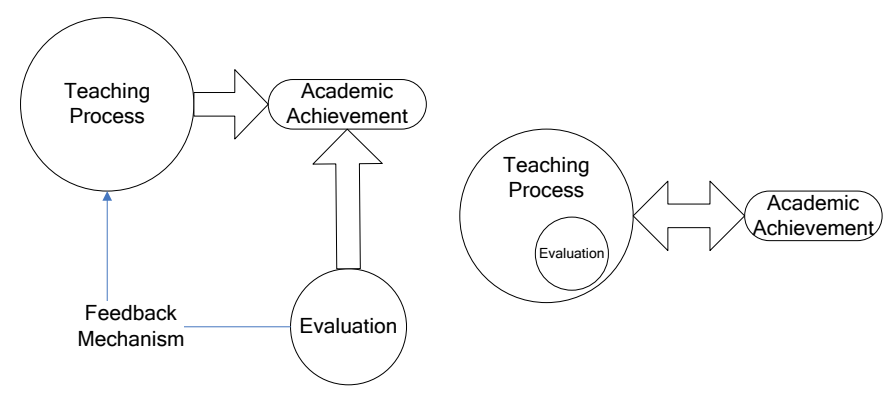

Fig. 1. The differences between traditional teaching and MOOC teaching

In the traditional teaching evaluation model, teachers can only be evaluated according to the students' learning results, and the feedback mechanism can be reflected in the teaching process after the suggestion is put forward, which undoubtedly increases the time cost of foreign language teaching. Meanwhile, the MOOC teaching evaluation pays more attention to the formative evaluation. The teacher can grasp the students' learning situation at any time and feedback the evaluation results to the teaching process, so as to adjust the teaching methods and patterns.

\section{FOREIGN LANGUAGE TEACHING EVALUATION BASED ON MOOC}

MOOC foreign language teaching highlights the main position of students. In view of the problem that the single terminative evaluation is difficult to reflect the actual learning situation of the students, the teaching evaluation of MOOC foreign language courses is mainly based on the formative evaluation, and it is realized with the summative evaluation.

\section{A. The second foreign language teaching model based on MOOC}

The difference between MOOC teaching and traditional classroom teaching lies in the student centered teaching process. The whole teaching process of the second foreign language course based on MOOC is composed of three parts: independent study before class, interactive communication in class and cooperative learning after class. All parts are realized through distributed teaching task, it shows as Fig. 2.

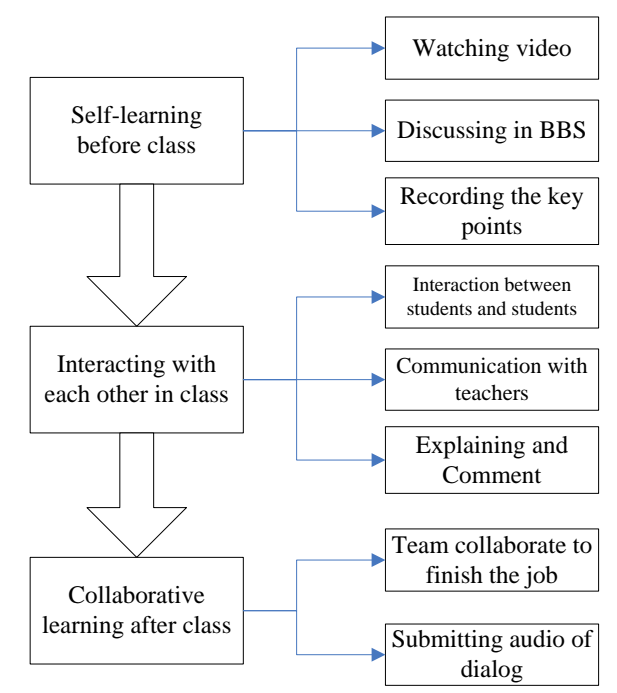

Fig. 2. Teaching process of second foreign language course based on MOOC

At first, the MOOC teaching of the second foreign language course requires students to watch the course video and courseware through PC, smart phone or PAD, and have a preliminary understanding of the knowledge points and key points of the course. Furthermore, it demands students discussing the knowledge points in the MOOC course forum and record the key points and difficulties in the course learning. That is the realization of autonomous learning in MOOC second foreign language curriculum.

Secondly, students can have a deeper understanding of curriculum knowledge through interaction and communication between teachers and students. And teachers focus on the difficulties and priorities recorded in the course of communication, and comment on the conclusion of learning and communicating with each other. That is the 
implementation content of MOOC second foreign language classroom interaction and interaction.

Finally, the teacher assigned MOOC to do after-school assignments in teaching second foreign languages. In order to reflect the formative evaluation of MOOC teaching better, after-school assignments must be completed by the group of students, so that students can cooperate with each other. For the second foreign language course, the task to be submitted is mainly the audio files that the group collaborates to complete the dialogue, which is required to be submitted on the MOOC teaching platform.

\section{B. The principle of teaching evaluation}

Because of the difference between the MOOC second foreign language teaching mode and the traditional classroom teaching model, the evaluation principle is very different. The teaching evaluation principle of the MOOC second foreign language course is mainly expressed in the following three aspects:

- MOOC teaching evaluation emphasizes the combination of formative assessment and summative assessment. Formative assessment pays attention to the whole process and links of the teaching mode, and it can play a role in adjusting and optimizing the teaching process. However, summative assessment focuses on the final evaluation of the whole teaching process, which is the final judgment of students. The combination of the two can make the MOOC second foreign language teaching mode continuously improve and perfect, and can observe the whole process of students' adaptation and progress and the final teaching effect.

- MOOC teaching evaluation demands the combination of scientific and operability. Scientific is the index of evaluation in accordance with MOOC second foreign language teaching process. For instance, the paper divided the second foreign language courses based on MOOC into two modules to design the index: daily module and final module, and design the first level indicators in three dimensions: video learning before class, classroom learning process, and summary of the effect after class, according to the specific teaching parts. Operability is the simplification and easy operation of the evaluation elements and evaluation criteria under the first level indicators.

- MOOC teaching evaluation embodies the combination of self-evaluation and others-evaluation. On the one hand, self-evaluation is a student's self-evaluation, which is a student's self-diagnosis, self-recognition and self-improvement. On the other hand, others-evaluation is the evaluation of the students by teachers and classmates, which reflects the objectivity of the evaluation and the collaboration between the students. The combination of the two is conducive to the diversification of the evaluation subject, the increase of the participation of the curriculum and the improvement of the evaluation index system, which makes the evaluators and the evaluators more likely to reach a consensus on the content of the evaluation and truly realize the evaluation and improvement.

\section{DESIGN OF EVALUATION SYSTEM}

Because of the characteristics of the MOOC second foreign language course teaching model taking the students as the main body of active learning, the formative evaluation of the process evaluation should occupy the main position, and the summative evaluation is supplemented. In the process of foreign language teaching in applied undergraduate colleges, it pays more attention to the cultivation of foreign language comprehensive application ability, including oral application, translation application and foreign trade application. Therefore, the evaluation weight needs to reflect the learning activities in daily teaching when we evaluate this kind of course. Taking the second foreign language teaching course as an example, the weight of the evaluation system can be designed as shown in Fig. 3.

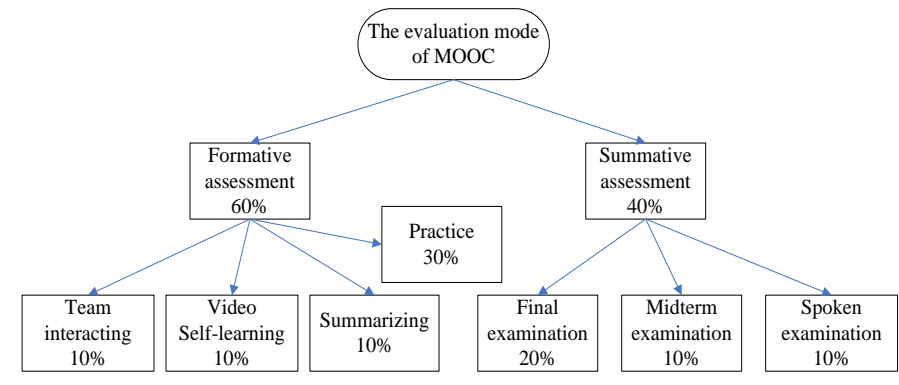

Fig. 3. An example of the weight distribution of the evaluation system

For the teaching based on the MOOC second foreign language courses, the main function of the evaluation is to monitor the MOOC learning process, provide timely feedback, and ensure the quality of learning. Therefore, the evaluation method of foreign language teaching based on MOOC should be a combination of formative assessment and summative evaluation.

Specifically, students can measure their goals by formative assessment by the teaching of MOOC second foreign language. It is possible for students to relearn, or to take a supplementary learning approach to a specific goal, or to adjust the progress and direction of the learning activity based on the results of the formative evaluation. Accordingly, the evaluation module and weight are shown in Table I as follows. 
TABLE I. THE EVALUATION MODULE AND WEIGHT

\begin{tabular}{|c|c|c|c|c|}
\hline \multirow{2}{*}{$\begin{array}{l}\text { Evaluation Module } \\
\text { and Weight }\end{array}$} & \multicolumn{4}{|c|}{ Weight Index } \\
\hline & First level index and weight & Second level index and weight & Evaluation Standard & $\begin{array}{c}\text { Ways of } \\
\text { Evaluation }\end{array}$ \\
\hline \multirow{8}{*}{$\begin{array}{l}\text { Formative } \\
\text { evaluation } \\
\quad(60 \%)\end{array}$} & \multirow{3}{*}{$\begin{array}{l}\text { 1. Independent study before class } \\
(30 \%)\end{array}$} & 1.1 Learning video (40\%) & $\begin{array}{l}\text { Whether to learn video } \\
\text { carefully }\end{array}$ & Self-evaluation by students \\
\hline & & 1.2 recording (40\%) & $\begin{array}{l}\text { Whether to take notes } \\
\text { seriously }\end{array}$ & Self-evaluation by students \\
\hline & & 1.3 complete the task ( $20 \%)$ & $\begin{array}{l}\text { Whether to accomplish the } \\
\text { task }\end{array}$ & Self-evaluation by students \\
\hline & \multirow{3}{*}{$\begin{array}{l}\text { 2. Classroom interaction and } \\
\text { interaction } \\
(30 \%)\end{array}$} & 2.1 Discussion (30\%) & $\begin{array}{l}\text { Whether to participate in } \\
\text { the discussion }\end{array}$ & Self-evaluation by students \\
\hline & & $\begin{array}{l}\text { 2.2 Practical operation training } \\
(40 \%)\end{array}$ & $\begin{array}{l}\text { Whether to finish the } \\
\text { operation training }\end{array}$ & $\begin{array}{c}\text { Evaluation } \\
\text { by teachers }\end{array}$ \\
\hline & & 2.3 Display and evaluation (30\%) & $\begin{array}{l}\text { Whether to participate in } \\
\text { the evaluation of display }\end{array}$ & $\begin{array}{l}\text { Others-evaluation by } \\
\text { students }\end{array}$ \\
\hline & \multirow{2}{*}{$\begin{array}{l}\text { 3. After-school cooperative } \\
\text { learning } \\
(40 \%)\end{array}$} & 3.1 After class summary & $\begin{array}{l}\text { Whether to finish the } \\
\text { summary after class }\end{array}$ & $\begin{array}{c}\text { Evaluation } \\
\text { by teachers }\end{array}$ \\
\hline & & 3.2 Finish the task & $\begin{array}{l}\text { Whether to finish the task } \\
\text { on time after class }\end{array}$ & $\begin{array}{l}\text { Evaluation } \\
\text { by teachers }\end{array}$ \\
\hline $\begin{array}{l}\text { Summative } \\
\text { Evaluation }\end{array}$ & $\begin{array}{l}\text { Final exam } \\
(100 \%)\end{array}$ & & The score of the final exam & $\begin{array}{l}\text { Evaluation } \\
\text { by teachers }\end{array}$ \\
\hline
\end{tabular}

In the course of MOOC learning in the second foreign language course, the formative evaluation is continuously applied in the way of quizzes, homework, file bag and nonquantitative evaluation of self-qualitative evaluation. It can highlight the external control significance of learning evaluation, stimulate students' learning consciousness, promote learning and ensure the improvement of learning quality in different degrees. Moreover, the summative evaluation of the students' learning effect can further understand the quality of the students' studies at the end of the term. It also can find out the existing problems, and summarize the experience.

\section{CONCLUSION}

In conclusion, foreign language teaching in applicationoriented colleges and universities requires not only to cultivate students' comprehensive ability to apply foreign languages, but also to cultivate students' autonomous learning ability. And the cultivation of this ability is difficult to be evaluated through the previous evaluation model, which requires a thorough study of the diversified evaluation model applicable to the training of talents in application-oriented colleges and universities. The MOOC teaching has made a fundamental reengineering of the educational process. On the basis of combining formative and terminative evaluation, the MOOC second foreign language curriculum provides a new way of thinking for the foreign language teaching evaluation of application-oriented colleges and universities.

\section{REFERENCES}

[1] Torrance, H. and Pryor, J. Developing formative assessment in the classroom: Using action research to explore and modify theory. British Educational Research Journal: 2001, 27(5):615-631.

[2] Boston, Carol. The Concept of Formative Assessment. ERIC Clearinghouse on Assessment and Evaluation College Park MD, USA, 2002.

[3] Assessment Reform Group. Assessment for Learning:10 research-based principles to guide classroom practice:2002,(2)

[4] Bloom, BS, Hastings, JT \& Madaus, GF. Handbook on Formative and Summative Evaluation of Learning [M]. New York: McGraw-Hill, 1971.

[5] F.S. Feng, Q.Q. Yu and X.M. Li, "Exploring the MOOC evaluation system in practice,” China University Teaching. 2015,(10):72-81,85.(In Chinese)

[6] Holec, H. Autonomy and Foreign Language Learning [M]. Oxford: Pergamon Press, 1981.

[7] L.Liu, Z.M.Liu and Y.Z.Luo, “Analysis of Three European Assessment Tools for Measuring MOOCs' Quality in Higher Education and its Implications”, Education Research, 2015, (5):57-65. (In Chinese)

[8] Y.J. Cai, G.Z.Ma and P.Chen, "Studying MOOCs' Idea and Design from the Perspective of Assessment for Learning”, China Educational Technology, 2016, (9):66-7. (In Chinese) 